\title{
First report of Strongyloides sp. (Nematoda, Strongyloididae) in Lutreolina crassicaudata (Didelphimorphia: Didelphidae)
}

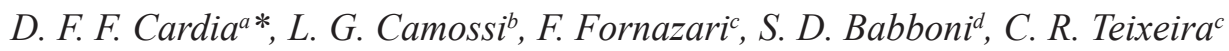 \\ and K. D. S. Bresciani ${ }^{b}$
}

\begin{abstract}
${ }^{\text {a} C e n t r o ~ U n i v e r s i t a ́ r i o ~ d e ~ S a ̃ o ~ J o s e ́ ~ d o ~ R i o ~ P r e t o ~-~ U N I R P, ~ R u a ~ I v e t e ~ G a b r i e l ~ A t i q u e, ~ 45, ~ B o a ~ V i s t a, ~}$ CEP 15025-400, São José do Rio Preto, SP, Brazil

${ }^{\text {b} D e p a r t a m e n t o ~ d e ~ A p o i o, ~ P r o d u c ̧ a ̃ o ~ e ~ S a u ́ d e ~ A n i m a l, ~ F a c u l d a d e ~ d e ~ M e d i c i n a ~ V e t e r i n a ́ r i a, ~ U n i v e r s i d a d e ~ E s t a d u a l ~}$ Paulista - UNESP, Rua Clóvis Pestana, 793, Dona Amélia, CEP 16050-680, Araçatuba, SP, Brazil

${ }^{\circ}$ Centro de Medicina e Pesquisa em Animais Selvagens, Faculdade de Medicina Veterinária e Zootecnia, Universidade Estadual Paulista - UNESP, Distrito de Rubião Junior, s/n, CEP 18618-970, Botucatu, SP, Brazil

dPrefeitura Municipal de Botucatu, Sáude Pública Veterinária, Rua Major Matheus, 7, CEP 18609-083, Botucatu, SP, Brazil

*e-mail: danielcardia@hotmail.com
\end{abstract}

Received: March 2, 2015 - Accepted: August 26, 2015 - Distributed: November 30, 2016

(With 1 figure)

\begin{abstract}
The present study reports the first case of the presence of the intestinal nematode Strongyloides sp. in fecal examinations of a male Lutreolina crassicaudata, considered a synanthropic marsupial species with zoonotic potential. The Willis technique was used for the diagnosis. Presence of typical eggs of Strongyloides species in feces was detected. A fecal culture was performed to obtain larval stages, free-living adults and infective third stage larvae (L3) of this nematode after seven days, which was morphologically identified as Strongyloididae. This is the first report of infection by Strongyloides sp. in a tick-tailed opossum from Brazil.
\end{abstract}

Keywords: opossum, helminth, Nematoda, Strongyloides.

\section{Primeiro registro de Strongyloides sp. (Nematoda, Strongyloididae) em Lutreolina crassicaudata (Didelphimorphia: Didelphidae)}

\begin{abstract}
Resumo
O presente estudo relata o primeiro registro da presença do nematódeo intestinal Strongyloides sp. em exames de fezes de um macho de Lutreolina crassicaudata, considerado um marsupial sinantrópico com potencial zoonótico. A técnica de Willis foi empregada no diagnóstico. Presença de ovos típicos de Strongyloides spp. foi detectada nas fezes. Uma coprocultura foi realizada para obtenção de estágios larvais, adultos de vida livre e larvas infectantes de terceiro estágio (L3) deste nematódeo após sete dias, os quais foram identificados morfologicamente como Strongyloididae. Este é o primeiro relato de infecção por Strongyloides sp. em uma cuíca de cauda grossa do Brasil.
\end{abstract}

Palavras-chave: cuíca, helminto, Nematoda, Strongyloides.

\section{Introduction}

Lutreolina crassicaudata popularly known as thick-tailed opossum is a small marsupial mammal belonging to the Order Didelphimorphia and Family Didelphidae (Gardner, 2005). These marsupials are seeking food and shelter in urban areas, due the destruction of their habitat and ecosystem, thus compounding the synanthropic fauna of cities (Rossi et al., 2006). This species is poorly studied, therefore the information on the helminth fauna of these mammals are scarce. In South America there are only two reports of the presence of gastrointestinal nematodes in L. crassicaudata.
The only records of these parasites were performed by Navone et al. (1991) in Argentina, which were identified for the first time, the nematodes Travassostrongylus yungaensis Navone et al. (1991) and Hoineffia simplicispicula Navone et al. (1991) (Trichostrongylidae), present in the small intestine. Also, Valente et al. (2001) in Brazil (Pelotas, Rio Grande do Sul State) reported Capillaria sp. (Trichuridae) and Aspidodera raillieti Travassos, 1913 (Aspidoderidae) in the small and large intestine of $L$. crassicaudata, respectively.

Strongyloides (Nematoda, Strongyloididae) has more than 60 species, which mostly parasitize the small intestine, 
especially the region of the duodenum of several mammals, including man and domestic species such as dogs, cats, cattle, sheep, goats, horses and pigs (Grove, 1989).

About 10 species of Strongyloides have been identified in mammals Brazilians (Vicente et al., 1997). However, in Brazilian marsupials there are few records of these nematodes. The only report in these animals was described by Froes (1976) in Didelphis aurita from Rio Grande do Sul, however in this study the morphological and biometric data from specimens found were insufficient for identification.

The species of Strongyloides presents peculiar life cycle, with two distinct stages: a free life with the presence of males and females and other parasite with only parthenogenetic females, which are inserted in the intestinal mucosa of the duodenum (Harvey and Viney, 2001), causing gastrointestinal disorders to hosts as cramping and diarrhea (Taylor et al., 2010). Infection with these nematodes occurs principally by active penetration of infective larvae on the skin, presents in the environment (Bowman, 2006).

Due to the lack of information regarding helminth fauna of these marsupials, the present work aims, report the first occurrence of Strongyloides sp. in L. crassicaudata.

\section{Material and Methods}

A male of L. crassicaudata was captured and cared for at the Centro de Medicina e Pesquisa em Animais Selvagens belonging to the Faculdade de Medicina Veterinária e Zootecnia - UNESP, in the municipality of Botucatu, State of São Paulo, after being attacked by a domestic dog.

To perform the coproparasitological examinations, a fecal sample, recently eliminated by $L$. crassicaudata specimen was collected and stored in sterile collection bottle. Immediately after collection, the technique of Willis (Ueno and Gonçalves, 1998) was performed.

Presence of typical embryonated eggs of Strongyloides spp. in its feces was detected. A fecal culture was performed to obtain larval stages and free-living adults and presence of infective third stage larvae (L3) with a notched tail, which is a characteristic of the Strongyloides species, was detected after seven days.

To obtain morphological and biometric data in order to identify the Strongyloides species involved in this parasitism from parthenogenetic females, artificial infection by subcutaneous inoculation, with insulin syringe and needle, of approximately 50 infective L3, taken from the same fecal culture by the Baermann technique (Ueno and Gonçalves, 1998) was performed in a male Wistar rat (Rattus norvegicus) with one month of age, created in conditions free of prior infection with other nematodes. After the first day of infection, the rat was subjected to daily coproparasitological analysis and euthanized at the end of the 12th day post-infection. The intestinal content was collected and analyzed in an attempt to recover parthenogenetic females.

\section{Results}

The Willis technique revealed eggs (Figure 1a) with typical morphological characteristics of the Strongyloides species, as thin and transparent shell with the presence of larvae inside. The fecal culture revealed different typical evolutionary stages of Strongyloides species as the first stage larvae (L1) and second stage larvae (L2), infective L3, plus free-living males and females. The L1 and L2 analyzed showed rhabditoid type esophagus, with body, isthmus distinct and clear bulb and tapered tail. However, the L2, different from that observed in the L1, it was observed elongated esophagus, with the division between the bulb and isthmus less evident and the presence of genital primordium. The infective L3 (Figure 1b) had elongated filarioid type esophagus and tapered tail end with incised (Figure 1c). Free-living females (Figure 1d) had the short body, slightly thick cuticle, rhabditoid type esophagus, didelphic and anfidelphic reproductive system, vulva close to half of the body, with prominent lips, uterus with a single row of eggs and tapered tail (Figure 1e). The free-living males (Figure 1f) had cylindrical body, rhabditoid type esophagus and two equal and symmetrical spicules, visible gubernaculum and pre-anal papillae and tapered tail.

The bioassay was not isolated Strongyloides species, therefore the presence of eggs in the feces or intestinal parthenogenetic female was not detected.

\section{Discussion}

This study reported the first case of Strongyloides sp. in L. crassicaudata. Several cases of parasitism by species of this genus of gastrointestinal nematode has been reported in Brazil, both in wild and domestic mammals (Vicente et al., 1997). However, records of these parasites were practically absent in marsupial species in Brazil and as in all of South America. Experimental infection in $R$. norvegicus was performed in this study aimed to the isolation and identification of species of the Strongyloides genus involved in the parasitism of this South American marsupial.

However, no parthenogenetic female could be recovered from this host, since the thick tailed opossum was reintroduced to the environment after appropriate veterinary treatment, aiming to contribute to the preservation of this species in nature.

To determine the species would be essential to obtain parthenogenetic females, however the isolation of this species of Strongyloides in Wistar rat may not have occurred probably as a consequence of the high specificity of the parasitic nematode with $L$. crassicaudata, or possibly the amount of larvae was not enough for the establishment of infection in the rat.

Thus, this marsupial is a new host recorded for Strongyloides sp. These finding raises the hypothesis that this kind of Strongyloides sp. can also be a zoonotic risk, since its host is already part of the synanthropic fauna of cities, and that some species of this nematode, 

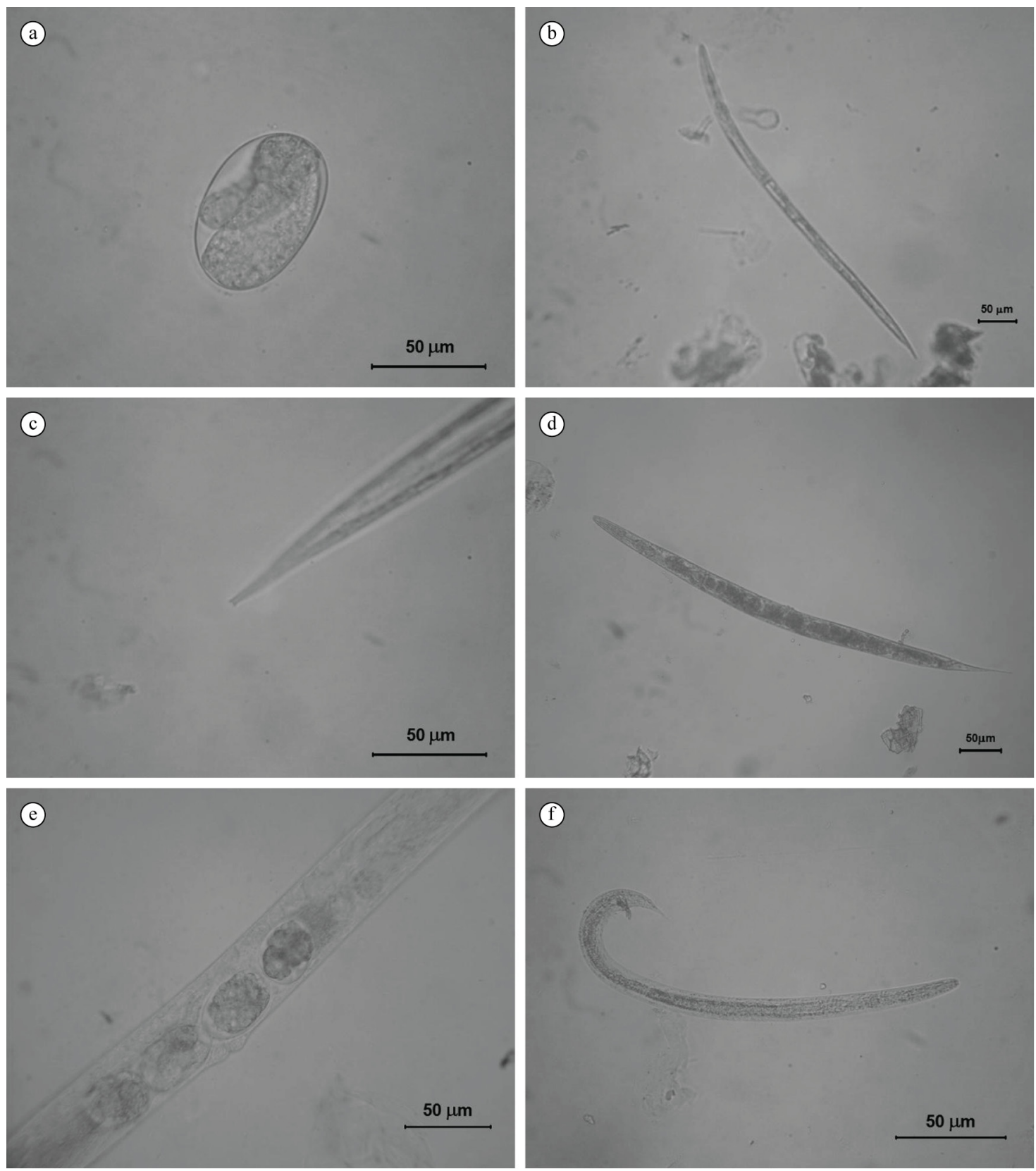

Figure 1. Egg of Strongyloides sp. recovered by the technique of Willis in fecal sample of Lutreolina crassicaudata (a); Infective third stage larvae (L3) of Strongyloides sp. (b); Notched posterior end of infective L3 of Strongyloides sp. (c); Free-living female of Strongyloides sp. (d); Uteri with a single row of eggs and prominent vulvar lips in free-living female of Strongyloides sp. (e); Free-living male of Strongyloides sp. (f).

such as S. stercolaris (Neves et al., 2005) are known to be transmitted from animals to the human population. This study contributes towards knowledge of the helminth fauna of sinantropic marsupials in Brazil.

\section{References}

BOWMAN, D.D., 2006. Parasitologia veterinária de Georgis. 8th ed. Barueri: Manole. 422 p.
FROES, O.M., 1976. Novos registros para a fauna parasitária do Rio Grande do Sul. Anais da Faculdade de Medicina de Porto Alegre, vol. 2, pp. 23-26.

GARDNER, A.L., 2005. Didelphimorphia. In: D.E. WILSON and D.M. REEDER, eds. Mammals species of the world. Baltimore: Johns Hopkins University, vol. 1, pp. 3-18.

GROVE, D.I., 1989. Strongyloidiasis: a major roundworm infection in man. London: Taylor \& Francis. 336 p. 
HARVEY, S.C. and VINEY, M.E., 2001. Sex determination in the parasitic nematode Strongyloides ratti. Genetics, vol. 158, no. 4, pp. 1527-1533. PMid:11514444.

NAVONE, G.T., SURIANO, D.M. and PUJOL, C.A., 1991. Travassostrongylus yungaensis $\mathrm{n}$. sp. and Hoineffia simplicispicula n. sp. (Nematoda: Trychostrongyloidea) from Thylamys venustus and Lutreolina crassicaudata (Marsupialia: Didelphidae) in the Northwest Argentina. Systematic Parasitology, vol. 19, no. 3, pp. 187-193. http://dx.doi.org/10.1007/BF00011886.

NEVES, D.P., MELO, A.L., LINARDI, P.M. and VITOR, R.W.A., 2005. Parasitologia humana. 11 th ed. São Paulo: Atheneu. 494 p.

ROSSI, R.V., BIANCONI, G.V. and PEDRO, W.A., 2006. Ordem Didelphimorphia. In: N.R. REIS, A.L. PERACCHI, W.A. PEDRO and I.P. LIMA, eds. Mamiferos do Brasil. Londrina: Universidade Estadual de Londrina, pp. 27-66.
TAYLOR, M.A., COOP, R.L. and WALL, R.L., 2010. Parasitologia veterinária. 3rd ed. Rio de Janeiro: Guanabara Koogan. 742 p.

UENO, H. and GONÇALVES, P.C., 1998. Manual para diagnóstico das helmintoses de pequenos ruminantes. 4th ed. Tokyo: Japan International Cooperation Agency. 143 p.

VALENTE, A.L.S., PAULSEN, R.M.M. and MÜLLER, G., 2001. Helmintos gastrointestinais da cuíca-de-cauda-grossa, Lutreolina crassicaudata (Mammalia: Marsupialia), no Rio Grande do Sul. In: Anais do $28^{\circ}$ Congresso Brasileiro de Medicina Veterinária (CONBRAVET), 2001, Salvador, Bahia. Salvador: Conbravet. 18 p.

VICENTE, J.J., RODRIGUES, H.O., GOMES, D.C. and PINTO, R.M., 1997. Nematódeos do Brasil. Parte V: nematódeos de mamíferos. Revista Brasileira de Zoologia, vol. 1, no. 14, pp. 1-452. 